\title{
Renewable power management: A review
}

\author{
Tonye Irims
}

Founder \& CEO at WiSolar

\section{April, 2020}

\section{Abstract}

For a decent quality of life, energy is important. And many people in the world do not have adequate electricity. It is important to provide sustainable and sufficient energy sourcesthat are not responsible for climate and emissions, and renewables offer a solution. In certain parts of the world, wind and solar farms will provide the cheapest electricity. In addition, all electricity demands in the world will be fulfilled. But, while market forces aid rapidly to switch from fossils to renewables, there are competing strains and challenges faced by the developed and developing countries.

The increasing clean, productive and sustainable energy fields have contributed to the creation of past experiments, which entail a transition to more sustainable energy management. Energy Management is a concept used to reduce and monitor the volume and expense of energy used to deliver a service. All systematic processes focused in the current study begins by examining the links between population, economy and energy consumption in the past, and analyzing the conventional and renewable sources of energy, as well as their management, in order to support ever-growing requirements for energy in the coming decades.

This report is also about the recent green energy management technologies as well as primary threats and risks. Potential new clean energy initiatives and policies in developed markets, along with high -level renewable management examples in emerging economies, are discussed. Finally, the study focuses on renewable energy management in operation from the frontline of energy insecurity in the industrialized world. The Researcher offers new frameworks for energy sustainability measurements, realistic approaches for the deployment of renewable energies and enhancement of efficiencies and specific insights into risk control in power generation plants. 


\section{Access options}

Rent or Buy article

Get time limited or full article access on ReadCube. from $\$ 8.99$

Rent or Buy

All prices are NET prices.

\section{Subscribe} to Journal

Get full journal

access for 1 year

$£ 185.90$

only $£ 3.65$ per issue

\section{Subscribe}

All prices include VAT for United Kingdom.

\section{References:}

[1] H. Kanchev, D. Lu, F. Colas, V. Lazarov, and B. Francois, "Energy management and operational planning of a microgrid with a PV-based active generator for smart grid applications," IEEE Trans. Ind. Electron., 2011.

[2] T. Energy, “Annual Energy Review,” 2010.

[3] E. D. Castronuovo and J. A. P. Lopes, "Optimal operation and hydro storage sizing of a wind-hydro power plant," Int. J. Electr. PowerEnergy Syst., 2004.

[4] M. Hassan, "Urbanization and CO2 emission in Bangladesh: The Application of STIRPAT model."

[5] Renewable Energy \& Energy Efficiency Partnership, "Energy efficiency technologies and benefits," Int. Energy Agency, 2012.

[6] US Department of Energy - Energy Efficiency and Renewable Energy, "What is the energy payback for PV?," Int. J., 2004. 
[7] International Renewable Energy Agency, "IRENA-IEA-ETSAP Technology Brief 4: Thermal Storage," IRENA and IEA-ETSAP, 2013.

[8] International Renewable Energy Agency, IRENA (2019), Global Energy Transformation: A Roadmap to 2050. 2019.

[9] T. Magradze, "TAX ADMINISTRATION IN THE RUSSIAN FEDERATION: CURRENT PROBLEMS AND DEVELOPMENT PROSPECTS," in Colloquium-journal, 2020, no. 5 (57).

[10] M. Tengiz, "APPLICATION OF GAME THEORYSIMULATION IN ENTERPRISE MANAGEMENT," in Colloquium-journal, 2020, no. 8 (60).

[11] M. Tengiz, "NEW METHODOLOGYOF EVALUATING THE EFFICIENCY OF MANAGERIAL DECISIONMAKING," in Colloquium-journal, 2020, no. 8 (60).

[12] T. Magradze, "MATHEMATICAL MO DELING IN THE ENTERPRISE MANAGEMENT," in Colloquiumjournal, 2020, no. 7 (59).

[13] D. JAPARIDZE and T. MAGRADZE, “OPTIMAL PLANNING OF OPERATIVE RESERVE OF ACTIVE POWER IN POWER SYSTEM UNDER CONDITIONS OF UNCERTAINTY," 2020.

[14] G. Nikitas, S. Bhattacharya, and N. Vimalan, "Wind energy," in Future Energy: Improved, Sustainable and Clean Options for Our Planet, 2020.

[15] R. Energy, "Renewable Energy Road Map. Renewable energies in the 21st century: building a more sustainable future," J. Int. Wildl. Law Policy, 2007.

[16] H. Lund, "Renewable energy strategies for sustainable development," Energy, 2007.

[17] A. M. Omer, "Energy, environment and sustainable development," Renewable and Sustainable Energy Reviews. 2008.

[18] S. Energy, "Powering our Lives : Sustainable Energy Management and the Built Environment Powering our Lives : Sustainable Energy Management and," Communities, 2008.

[19] E. Serrano, G. Rus, and J. García-Martínez, "Nanotechnology for sustainable energy," Renewable and Sustainable Energy Reviews. 2009.

[20] Y. H. V. Lun and S. L. D. Tung, "Sustainable energy," in Green Energy and Technology, 2020.

[21] I. Vera and L. Langlois, "Energy indicators for sustainable development," Energy, 2007.

[22] S. M. Shafie, T. M. I. Mahlia, H. H. Masjuki, and A. Andriyana, "Current energy usage and sustainable energy in Malaysia: A review," Renewable and Sustainable Energy Reviews. 2011.

[23] U.. D. of E. Office of Energy Efficiency and Renewable Energy, "The Economic Benefits of Sustainable Design," Chief Exec., 2006.

[24] I. Dincer, "Renewable energy and sustainable development: A crucial review," Renew. Sustain. energy Rev., 2000.

[25] M. A. Uqaili and K. Harijan, Energy, environment and sustainable development. 2012.

[26] M. Hassan, "Exploring the Nexus between Knowledge Economy and Green Economy," Available SSRN 3574409, 2020. 
